\title{
REPERTUAR MUZYCZNY CELEBRACJI SAKRAMENTU MAŁŻEŃSTWA. ASPEKT MEDIALNY, KULTUROWY I LITURGICZNY
}

Dobór repertuaru muzycznego na celebrację sakramentu małżeństwa jest przedmiotem coraz częstszych dyskusji. Zadawane są pytania o dowolność tej selekcji i istnienie nieprzekraczalnych granic, które wyznaczają obowiązującą poprawność. Kolejne wątpliwości dotyczą takich kwestii jak: kto ma dokonywać takich wyborów i czym powinien się kierować przy podejmowaniu decyzji, kto ponosi odpowiedzialność za ostateczny przebieg uroczystości. Zarówno publikowane w środkach społecznego przekazu treści, jak i promowane kulturowe rozwiązania nie tylko przekonują o aktualnie istniejącej konieczności wskazania problemu, lecz także ukazują potrzebę podjęcia próby jego rozwiązania.

Muzyczny repertuar świętych celebracji wymaga od teologów nieustannego trudu właściwej oceny zarówno w kontekście liturgicznym, jak i kulturowo-medialnym. Chociaż nauka Kościoła pozostaje niezmienna, to jednak musi się ona zmierzyć z próbami zmieniania jej przez promowany we współczesnej kulturze i środkach społecznego przekazu świecki charakter kościelnych obrzędów. Potrzebę taką uzasadniają zarówno treści nauczania ostatnich papieży, jak i wydawane dokumenty Kongregacji Kultu Bożego i Dyscypliny Sakramentów oraz Konferencji Episkopatu Polski. ${ }^{1}$ Powszechnie znane są opinie -

Por. Święta Kongregacja Obrzędów, Instrukcja „Musicam Sacram” o muzyce w świętej liturgii (5 III 1967); Kongregacja ds. Kultu Bożego i Dyscypliny Sakramentów, Instrukcja „Redemptionis Sacramentum” o tym, co należy zachowywać, a czego unikać w związku z Najświętsza Eucharystia (25 III 2004); Instrukcja 
wyrażane przez takich teologów i muzykologów jak kard. Joseph Ratzinger czy ks. Ireneusz Pawlak - że stan muzyki w Kościele jest zły, należy stanowczo przeciwstawiać się wszelkim zagrożeniom dla właściwego repertuaru dla liturgii, pilnym zadaniem jest też dbałość o estetyczny wymiar sprawowanych obrzędów. ${ }^{2}$

Wybrane zagadnienie zaprezentowane zostanie w trzech częściach. Pierwszą stanowi przedstawienie problemu, drugą wskazanie przyczyny jego istnienia, trzecią wypełnią treści uzasadniające pilną potrzebę podania poprawnych rozwiązań dyskutowanych kościelnych kwestii oraz nauki Kościoła na temat muzyki liturgicznej. Artykuł jest próbą uzasadnienia aktualności dobrze znanej teologom i muzykologom kwestii, którą zajmują się od II Soboru Watykańskiego. Na wskazanej wówczas drodze odnowy liturgii znajdują się wytyczne dotyczące muzycznego repertuaru celebracji sakramentów świętych. Prezentacja wybranego zagadnienia ma pokazać, jak przedstawia się liturgiczne życie Kościoła w świetle wykonywanej w tej wspólnocie muzyki. Podejmowany wielokrotnie temat należy obecnie zobaczyć także w aspekcie kulturowo-medialnym. Zarówno zmieniające się kulturowe trendy, jak i używanie - w celu pozyskania informacji oraz wymiany opinii - mediów społecznościowych wywiera znaczący wpływ nie tylko na przedstawianie problemu muzyki kościelnej, lecz także na jego rozwiązanie. Zastosowaną metodę stanowi procedura interpretacji sub ratione Dei: najpierw dyskutowana kwestia zostanie rozpoznana w świetle powszechnie dostępnego przekazu medialnego oraz faktu ulegania w kościelnych celebracjach kulturowym trendom, a następnie opisana z punktu widzenia nauki Kościoła. Obecny

Episkopatu Polski o muzyce liturgicznej po Soborze Watykańskim II (8 II 1979); Instrukcja Konferencji Episkopatu Polski o muzyce kościelnej (14 X 2017); A. Jeż, List pasterski Biskupa Tarnowskiego na temat roli muzyki w liturgii z okazji jubileuszu 50-lecia działalności Diecezjalnego Studium Organistowskiego w Tarnowie (10 XI 2015), http://czermna.diecezja.tarnow.pl/?list-pasterski-biskupa-tarnowskiego-na-temat-roli-muzyki-w-liturgii (dostęp: 5 VII 2019).

2 Por. I. Pawlak, Muzyczna kultura Kościoła - zagrożona, Liturgia Sacra 9(2003) nr 1, s. 91; T. Lisiecki, Problemy formacji muzycznej duchownych w Polsce, Roczniki Teologiczne 63(2016) nr 8, s. 108-109. 
będzie także komponent praktyczno-dialogiczny, który pozwoli na podanie implikacji liturgicznych.

\section{Dostrzeżenie problemu, czyli o medialnych treściach na temat liturgii ślubnej}

Autorzy utworzonego dla zainteresowanych uroczystością zaślubin portalu www.abcslubu.pl pomagają przygotowującym się do zawarcia sakramentu małżeństwa $\mathrm{w}$ znalezieniu odpowiedzi na pytania: „Jakie utwory powinny być grane w Kościele podczas sakramentu ślubu? Jaką muzykę wybrać na ślub w Kościele?". ${ }^{3}$ Zespół portalu - określający siebie ekspertami w branży ślubnej - podaje propozycje utworów, które warto wybrać na taką wyjątkową uroczystość. ${ }^{4}$ Poszukujący pomocy w omawianej kwestii przekonywani są do skorzystania z podanej listy następującymi argumentami: spis utworzony został przez „szkolonego niegdyś w liturgii animatora muzycznego” ze zdanym w tej dziedzinie egzaminem; pozyskiwaniu tytułów towarzyszyła wiedza, że święte celebracje rządzą się sobie właściwymi regułami; wybrany utwór nie może narażać uczestników liturgii na tzw. reakcję karaoke - słyszana melodia skutkuje przywołaniem tekstu, który nie odpowiada treściom uroczystości zaślubin; jeśli asystujący przy zawieraniu małżeństwa kapłani przyczyniają się do „dziwnych z punktu widzenia liturgii rozwiązań”, to ostatecznie - co może nawet jest dobre - bezskuteczna jest troska o jego poprawność liturgiczną; swoje muzyczne marzenia, które nie do końca odpowiadają kościelnym normom, nowożeńcy mogą spełniać w utworach na początku i na końcu mszy. Zamieszczone rady puentowane są

3 D. Barwiński, Jakie utwory mogą być grane na ślubie w Kościele, https:// www.abcslubu.pl/slub-i-wesele/muzyka-na-wesele/4720/jakie-utwory-moga-byc-grane-na-slubie-w-kosciele (dostęp: 14 VIII 2019).

4 Na liście ślubnych propozycji znalazły się m.in. takie utwory, jak: Ave Maria i Marsz weselny (wersje różnych kompozytorów), Hallelujah Leonarda Cohena, Marzenie Roberta Schumanna i Obój Gabriela (muzyka z filmu Misja) Ennio Morricone. 
zaleceniem, że zawsze „wypada trzymać powagę, styl, jak i prześledzić co to dokładnie za utwór, jak powstał, jaki ma tekst itd.". ${ }^{5}$

Szukający rozwiązań problemów z wyborem utworów na uroczystość zawarcia sakramentalnego związku małżeńskiego za pomocą utworzonego dla nich portalu natrafiają na głosy komentatorów, które jednak nie ułatwiają rozstrzygnięcia tej trudnej kwestii. Umieszczone pod tekstem komentarze podają nie tylko nowe, lecz także znaczące argumenty, takie jak: powszechnie powtarzana opinia o niemoralnym życiu kapłanów dyskwalifikuje ich jako oceniających prawidłowość ślubnego repertuaru; w przypadku odrzucenia przez księdza podanej przez nowożeńców propozycji śpiewów należy wpłynąć na zmianę tej decyzji przez podarowanie mu koperty z pieniędzmi; przygotowany do wykonania na mszy świętej (z polskim - typowo religijnym, ślubnym - tekstem) utwór Hallelujah nie mógł być zaśpiewany ponieważ napisał go ateista. Kolejnym komentatorskim argumentem, który jest swoistego rodzaju apelem o opamiętanie się kapłanów w wydawaniu zakazów i wyrażaniu sprzeciwu odnośnie do wybranego przez decydujących się na sakramentalne małżeństwo repertuaru jest spadająca liczba zawierających taki związek: „Niedawno byłam na ślubie i ksiądz bardzo ubolewał nad małą ilością udzielanych sakramentów małżeństwa. Niech kler dalej tak robi, to coraz więcej ludzi będzie odsuwało się od Kościoła". ${ }^{6}$

Przywołany medialny przekaz o liturgii ślubnej należy uzupełnić o podane w środkach społecznego przekazu treści, które przekonują, że istniejący problem znany jest wspólnocie Kościoła katolickiego. W październiku 2017 r. Konferencja Episkopatu Polski opublikowała instrukcję poświęconą muzyce liturgicznej. Jej wydanie - o czym informowały środki masowego komunikowania ${ }^{7}$ - uzasadniła wy-

\section{Tamże.}

6 Ewelina, Komentarz. Coraz mniej ślubów (23 VI 2018), https:/gazetakrakowska.pl/powstanie-lista-piosenek-zakazanych-na-slubie-tych-utworow-juz-nie-uslyszysz/ar/13277201 (dostęp: 14 VIII 2019).

Por. JZ//rzw / tvn24, ,, Nie każdy instrument odpowiada godności świątyni”. Co i jak może grać w kościele, https://www.tvn24.pl/wiadomosci-z-kraju,3/biskupi-przyjeli-instrukcje-o-muzyce koscielnej,781531.html (dostęp: 5 VII 2019); Episkopat. 
raźnymi zmianami, jakie zachodzą w życiu społecznym i kulturowym, które świadczą o dokonującej się sekularyzacji codziennej egzystencji. Jednym ze sposobów zareagowania na obecny stan było wydanie dokumentu określającego zasady doboru repertuaru na liturgię sakramentu małżeństwa. Treści wypełniające wspominaną instrukcję stanowią odpowiedź na rozpoznanie jednej z przyczyn dostrzegalnej sekularyzacji, jaką jest nieznajomość nauki Kościoła. ${ }^{8}$ Warto w tym miejscu dopowiedzieć, że na coraz częściej dostrzegalną w życiu współczesnego człowieka postawę ignorowania przepisów kościelnych wskazywała kilka lat wcześniej jedna z watykańskich kongregacji charakteryzując kult związany z Najświętszą Eucharystią. ${ }^{9}$

O tym, jak istotne znaczenie dla wiernych ma wciąż aktualny i nieustannie wskazywany przez Kościół problem, świadczyć mogą podejmowane stanowcze próby jego rozwiązania. Pierwszym przykładem może być instrukcja, jaką biskup kielecki wydał dla swoich diecezjan: w listopadzie 2018 r., w liturgiczne wspomnienie św. Cecylii - patronki muzyki kościelnej, opublikował wytyczne dotyczące liturgicznego repertuaru muzycznego. W jednym z punktów dokumentu, którego treść dotyczy uroczystości zawierania sakramentalnego związku małżeńskiego, wyraźnie zapisane zostały normy wskazujące na właściwie i błędnie dobierany repertuar. ${ }^{10}$ Podawane wówczas, w świeckich środkach społecznego przekazu, informacje

pl.om, Episkopat wydat instrukcję o muzyce kościelnej. Koniec pobłażliwości dla „Hallelujah” ze Shreka, https:/www.pch24.pl/episkopat-wydal-instrukcje-o-muzyce-koscielnej-koniec-poblazliwosci-dla-hallelujah-ze-shreka,55401,i.html (dostęp: 5 VII 2019).

8 Por. Instrukcja Konferencji Episkopatu Polski o muzyce kościelnej (14 X 2017), nr 3, 30g.

9 Por. Kongregacja ds. Kultu Bożego i Dyscypliny Sakramentów, Instrukcja „Redemptionis Sacramentum” o tym, co należy zachowywać, a czego unikać w związku z Najświętsza Eucharystią (25 III 2004), nr 7, 9.

10 J. Piotrowski, Instrukcja dotyczaca muzyki i śpiewu liturgicznego dla diecezji kieleckiej (22 XI 2018), http://www.diecezja.kielce.pl/sites/default/files/ instrukcja_dotyczaca_muzyki_i_spiewu_liturgicznego_dla_diecezji_kielckiej. pdf (dostęp: 14 VIII 2019). 
o wydanym przez biskupa zakazie wykonywania podczas liturgii utworów o charakterze świeckim oznaczone były takimi tytułami jak: Tych piosenek nie ustyszysz na ślubie. Na liście Abba, The Beatles czy Leonard Cohen, ${ }^{11}$ Piosenek Abby i Beatlesów na ślubie nie ustyszymy. Biskup wydat instrukcję. ${ }^{12}$ Nie bez znaczenia pozostaje także fakt, że przekazywanie rzeczonej informacji komentowane było opiniami o - stawianych przez Kościół - zbyt wysokich wymaganiach. Taki przekaz potwierdza choćby tekst zamieszczony w „Gazecie Wyborczej”: „Oczywiście nie chodzi o to, żeby grać w kościele nie wiadomo co, ale jednak te obostrzenia są zbyt rygorystyczne. Ślub to prywatna i bardzo ważna uroczystość dwojga ludzi. Byłoby dobrze, gdyby mogli go mieć taki, jak sobie wymarzyli’. ${ }^{3}$

W medialnym przekazie dotyczącym liturgii ślubnej nie można pominąć prezentacji wyniku sondy Waszym zdaniem z kierowanym do czytelników internetowego portalu Fakt.pl pytaniem: „Podoba ci się idea listy «piosenek zakazanych»?". W rzeczonym badaniu oddano (od 22 czerwca 2018 do 19 marca 2019) 105 głosów. ${ }^{14}$ Odpowiedzi pozytywne (,Tak”) stanowiły 18\%, a negatywnych („Nie”) było $82 \%$.

W celu dokładniejszego przedstawienia podjętego tematu, warto wskazać choćby kilka, najbardziej charakterystycznych, opinii o wykonywanym podczas zawierania sakramentalnego związku muzycznym repertuarze: wyraźnie przekazane ustalone reguły mogą przyczynić się do uporządkowania różnych praktyk w niniejszej kwestii, wcześniejsze podanie norm i ścisłe ich przestrzeganie nie

11 Ł. Jaćkiewicz, Tych piosenek nie ustyszysz na ślubie. Na liście Abba, The Beatles czy Leonard Cohen, https://allaboutmusic.pl/biskup/ (dostęp: 27 IV 2019).

12 M. Wadowski, Piosenek Abby i Beatlesów na ślubie nie ustyszymy. Biskup wydat instrukcje, http://kielce.wyborcza.pl/kielce/7,47262,24218674,piosenek-abby-i-beatlesow-na-slubie-nie-uslyszymy-biskup-wydal.html?disableRedirects=true (dostęp: 27 IV 2019).

13 Tamże.

14 IB, Tego nie ustyszysz na ślubie. Powstanie lista „piosenek zakazanych”? https://www.fakt.pl/wydarzenia/polska/krakow/tarnow-powstanie-lista-piosenek-zakazanych-na-slubie/lxrly5j (dostęp: 14 VIII 2019). 
dopuściłoby do istniejącego obecnie problemu, należy poszukiwać odpowiedzi na pytanie o skuteczniejsze respektowanie istniejących już rozwiązań, posłuszeństwo względem podawanych w Kościele norm pozwala dostrzec i zachować piękno liturgii, nieustanne pomnażanie zakazów decyduje o negatywnym postrzeganiu wspólnoty Kościoła. ${ }^{15}$

\section{Kulturowa pułapka, czyli błędne rozumienie celebracji sakramentu małżeństwa}

W prezentacji podjętego zagadnienia, w którym z łatwością dostrzega się praktykę niewłaściwego doboru repertuaru na uroczystość zawarcia sakramentalnego związku małżeńskiego, nie można pominąć wskazania przyczyn istniejącej sytuacji. Jedną z nich o czym przekonują treści medialnych przekazów - są dostrzegalne obecnie współczesne trendy kulturowe. Pierwszym z nich jest moda na muzykę pochodzącą z filmów. Problem ten polega na tym - jak wyczytać można w opiniach użytkowników przekazu internetowego - że współczesny człowiek żyje w kulturze obrazowej i jego pragnienia (szczególnie ludzi młodych) odnoszą się do oglądanych filmów. W oglądanych produkcjach znaczącą rolę odgrywa muzyka, przez którą wytwarza się najpiękniejszy klimat-serdeczności, podniosłości, uroczystości i miłości. ${ }^{16}$ Zapewne dlatego rozpowszechnia się praktyka wybierania na ślub repertuaru, którego podstawą są przemijające wrażenia, fantazja czy też pełne emocji marzenia. ${ }^{17}$

15 M. Lewandowski, Decyzja dot. ,zakazanych piosenek” wywołała goraca dyskusję. Oto najciekawsze komentarze, https://www.deon.pl/religia/kosciol-i-swiat/z-zycia-kosciola/art,34667,decyzja-dot-zakazanych-piosenek-wywolala-goraca-dyskusje-oto-najciekawsze-komentarze.html (dostęp: 17 IV 2019).

16 Por. Krupor, Komentarz (12 VIII 2017), https://www.abcslubu.pl/slub-i-wesele/muzyka-na-wesele/4720/jakie-utwory-moga-byc-grane-na-slubie-w-kosciele\#comment31383 (dostęp: 31 V 2019).

17 Por. W. Batycki, Muzyka w czasie liturgii sakramentu matzeństwa (17 listopada 2016), https://diecezja.zamojskolubaczowska.pl/wiadomosci/1137-muzyka-w-czasie-liturgii-sakramentu-malzenstwa (dostęp: 14 VIII 2019); Ł. Bobek, Kościelisko. Ślub w stylu Gwiezdnych Wojen, https:/gazetakrakowska.pl/ 
W medialnym przekazie, w muzycznych propozycjach celebracji ślubnych, znajdują się m.in. utwory z filmów Love story, Indiana Jones, Misja, Gwiezdne wojny czy Shrek.

Wskazaną praktykę potwierdza fakt zapraszania na te liturgiczne uroczystości muzyków grających na skrzypcach lub na wiolonczeli czy altówce. Dźwięk tych instrumentów buduje bowiem wzruszający klimat, który często nazywany jest „magicznym” bądź „mistycznym”. Dźwięk skrzypiec określany jest jako „dostojny” i „,ciepły”. ${ }^{18}$ Panująca obecnie moda wyraża się w przekonaniu: „Kwartet smyczkowy to wprost genialny zespół nie tylko do kościoła, ale i na obiadową część przyjęcia weselnego". ${ }^{19}$

Opisane powyżej typowe i przeciętne zachowania nowożeńców tłumaczą wyrażany często pogląd: „To nie pieśni są problemem, a podejście ludzi, którzy biorą ślub, bo wypada, albo bo ładnie wygląda. Niestety, wiele takich dzisiaj... może tym się martwmy?". ${ }^{20}$ Obowiązującą praktyką - która nie tylko wydaje się najskuteczniejszym rozwiązaniem przedstawianego problemu, lecz także promowana jest w mediach społecznościowych - wydaje się wypełnienie następujących zaleceń:

- informacje o tym, które utwory są trendy i co jest modne, mają eksperci - to ich należy zapytać;

- poznanie i wybranie piosenek modnych (będących na topie) sprawia, że nowożeńcy postrzegani są jako oryginalni i modni. ${ }^{21}$

koscielisko-slub-w-stylu-gwiezdnych-wojen-galeria/ar/9222380 (dostęp: 31 V 2019); G. Doniec, Dlaczego na ślubie nie będzie Alleluja ze Shreka? https:/www.liturgia. pl/Dlaczego-na-slubie-nie-bedzie-Alleluja-ze-Shreka/ (dostęp: 31 V 2019).

18 Por. Skrzypaczka. Wokal. Skrzypce na ślub i inne uroczystości, https://www. weselezklasa.pl/ogloszenia-weselne/skrzypaczka-na-slub-i-inne-uroczystosci-koscielne,32248/ (dostęp: 31 V 2019).

19 Por. Jak dobrać muzykę na ślub w kościele? https://www.slubnaglowie.pl/ inspiracje/artykul/jak-dobrac-muzyke-na-slub-w-kosciele, (dostęp: 701 2019).

20 Muzyk, Skrzypek, Chrześcijanin, Wierzący, Praktykujący, Komentarz (15 X 2017), http://piosenkireligijne.pl/piesni-na-slub/ (dostęp: 7 I 2019).

${ }_{21}$ Por. Piosenki na ślub kościelny i cywilny - najmodniejsze piosenki ślubne, https://www.eska.pl/news/piosenki-na-slub-koscielny -i-cywilny -najmodniejsze-piosenki-slubne-aa- PEEh-p1Zq-FKxj.html (dostęp: 31 V 2019). 
W tym miejscu prezentacji zagadnienia braku znajomości poprawnego celebrowania sakramentu małżeństwa i podejmowaniu decyzji z nim związanych zgodnie z panującymi standardami warto powrócić do stwierdzania, że nowożeńcy chcą zrealizować przechowywane w sercach marzenia, zaznaczyć własną pomysłowość czy przeżyć coś niezwykłego i spektakularnego. W każdym z takich przypadków, jak informuje „Gazeta Krakowska”, odpowiedzialni za przebieg celebracji duchowni „często muszą ścierać się z najróżniejszymi wizjami narzeczonych, które nie zawsze przystają do powagi liturgii i sakramentu, który mają przyjąć”. ${ }^{22}$

Prawdę o błędnym rozumieniu celebracji sakramentu małżeństwa potwierdzają także podawane w środkach społecznego przekazu dane statystyczne, które świadczą o konsekwentnie zmniejszającej się liczbie Polaków zawierających związek małżeński. Wskazana sytuacja pozwala stwierdzić, że współczesna kultura wywołuje coraz słabszą presję na zawarcie związku sakramentalnego. Tworzona przez małżonków wspólnota jest zatem kulturowo osłabiona. Dostrzeganie takiego stanu stanowi dla wielu okazję do spontanicznego wyrażenia błędnych opinii, że do praktyki życia w nieformalnych i niesakramentalnych związkach przyczyniają się księża. Ich wina polega na tym, że zamiast zachęcać do sakramentu małżeństwa, zniechęcają do jego przyjęcia. Dowodem takiego działania jest wydawanie kolejnych nakazów i zakazów, które nie tylko nie podobają się wiernym, lecz także zniechęcają do uczestniczenia w uroczystościach kościelnych. Zamiast otwierania kościołów dla wszystkich, dostrzegalne jest zamykanie ich dla osób myślących inaczej. W ten sposób na pewno nie dokona się ożywienie wiary młodych ludzi. Tak rozumiane są, wydawane przez biskupów i respektowane przez duszpasterzy, normy dotyczące muzyki i śpiewu liturgicznego. ${ }^{23}$

22 Por. AK, Powstanie lista ,piosenek zakazanych” na ślubie. Tych utworów już nie ustyszysz! https://gazetakrakowska.pl/powstanie-lista-piosenek-zakazanych-na-slubie-tych-utworow-juz-nie-uslyszysz/ar/13277201 (dostęp: 31 V 2019).

23 Por. L. Piotrowska, Czarna lista piosenek na ślub kościelny. Biskup zakazat kolejnych hitów, https://www.papilot.pl/zwiazki/slub-i-wesele/43009/ 
Zarówno niezrozumienie obrzędów małżeńskich i obwinianie duchownych za osłabianie wiary wiernych, jak i żądanie otwarcia się Kościoła na współczesne trendy kultury potwierdzają komentarze następującej treści: „A dlaczego nie można uwielbiać Boga świecką piosenką? O miłości i o sensie życia? Przecież treść może być Boża, mimo że świecka. Bez sensu... to nie wzmocni wiary tylko zirytuje, że «Kościołowi znowu się coś nie podoba». Nie jestem wrogiem Kościoła, ale w tak mało istotnej kwestii jak to, że piosenka jest świecka czy nieświecka to biskupi przesadzili”;24 „Ja bym wolała Metallice na swoim ślubie (...). Daj namiary na księdza, który się zgodzi”. ${ }^{25}$ Zacytowane opinie, świadczące o aktualności podjętego w obecnej prezentacji tematu, zamieszczane są pod artykułami o oprawie muzycznej ślubu - zawierającymi propozycje utworów na tę kościelną uroczystość.

\section{Aktualna i pilna potrzeba rozwiązania problemu}

Przedstawienie medialnego opisu problemów związanych z oprawą muzyczną liturgii ślubnej oraz wpływu kulturowych trendów na ustalanie tego repertuaru potwierdzają konieczność wytłumaczenia, na czym polega właściwy dobór utworów. Jedynie rzetelne poznanie nauki Kościoła na temat celebracji sakramentów świętych może rozpocząć zmianę błędnego pojmowania rozumienia kościelnych uroczystości i niewłaściwego ich sprawowania. Na takie rozwiązanie wskazuje w swoim nauczaniu Kościół, który w soborowym dokumencie o świętych celebracjach zaleca nieustanną troskę o wychowanie liturgiczne wiernych i kierowaną do ludu chrześcijańskiego katechezę liturgiczną. W ten sposób, wszyscy gromadzący się na

piosenki-zakazane-w-kosciolach (dostęp: 19 III 2019); M. Rymsza, Matżeństwo nie jest sprawa prywatna, http://wiez.com.pl/2017/02/03/malzenstwo-nie-jest-sprawa-prywatna/ (dostęp: 31 V 2019).

24 L. Piotrowska, Czarna lista piosenek na ślub kościelny.

25 Oprawa muzyczna ślubu-propozycje piosenek. Komentarze, https://zaplanuj-wesele.pl/oprawa-muzyczna-slubu-propozycje-piosenek/\#comments (dostęp: $31 \mathrm{~V}$ 2019). 
sprawowanie kultu, będą mogli łatwo zrozumieć święte czynności i uczestniczyć w nich w sposób czynny i świadomy. ${ }^{26}$

Poprawne przeżywanie liturgii - jak tłumaczy ks. prał. Marco Frisina, włoski kompozytor wielu utworów z zakresu muzyki sakralnej, odpowiedzialny za muzyczną oprawę uroczystości religijnych w Watykanie - „może być realizowane jedynie wówczas, kiedy każdy z uczestniczących uzyska wzrost świadomości i wiedzy na temat celebrowanych misteriów wiary i zaangażuje się osobiście w ich sprawowanie". ${ }^{27}$ Warto dodać, że o wskazywanym przez Kościół rozwiązaniu przypomniał w swoim komentarzu użytkownik portalu www.abcslubu.pl: ,...warto dokształcić się w zakresie liturgii Kościoła rzymskokatolickiego. Podczas sprawowania świętych obrzędów może być wykonana tylko taka muzyka, która jest jej integralną częścią. Dziś już są na ten temat książki, artykuły, instrukcje. Warto czytać, poznać ducha i sens liturgii świętej, a potem ją współtworzyć na chwałę Boga i pożytek wiernych". ${ }^{28}$

Rozwiązanie problemów związanych z repertuarem muzycznym celebracji sakramentu małżeństwa, które odnajdywać należy w nauczaniu Kościoła, tworzyć będzie treść niniejszej części artykułu. Przywoływane fragmenty tego nauczania stanowić będą odpowiedź na najczęściej podawany medialny przekaz o ślubnych uroczystościach - związane z nimi zadawane pytania, wyrażane opinie, dyskutowane rozwiązania. Do podejmowanych zagadnień należą z pewnością następujące kwestie:

1. Jakie jest podstawowe kryterium rozstrzygające o tym, czy utwór nadaje się do wykonania podczas mszy św. z udzieleniem sakramentu małżeństwa?

26 Por. KL 19, 21, 35.

27 Cyt. za: P. Maciaszek, Naznaczyć życie muzyka liturgiczną. Rozmowy o roli muzyki w różnych wyznaniach chrześcijańskich, Częstochowa 2012, s. 20.

28 ME, Komentarz (1 V 2018), https://www.abcslubu.pl/slub-i-wesele/muzyka-na-wesele/4720/jakie-utwory-moga-byc-grane-na-slubie-w-kosciele\#comment31656 (dostęp: 14 VIII 2019). 
2. Czy istnieje możliwość zaakceptowania wybranego przez nowożeńców, niezgodnego z normami liturgicznymi, repertuaru, który - ich zdaniem - nadaje celebracji bardziej uroczysty charakter i cieszy się obecnie szczególną popularnością (jest modny)?

3. Czy stawiane przez Kościół - odnośnie do repertuaru ślubnego - wymagania nie są zbyt nadmierne? Czy o ich zbytnim wygórowaniu nie świadczą takie fakty, jak wyrażanie zgody przez księży na wykonywanie niewłaściwych utworów czy też coraz mniejsza liczba wiernych zawierających sakramentalny związek?

4. W jaki sposób Kościół odpowiada na powszechnie wyrażane w mediach (szczególnie społecznościowych) opinie, że winę za coraz częściej praktykowane życie w związkach nieformalnych i niesakramentalnych ponoszą kapłani; oni bowiem zniechęcają do sakramentu małżeństwa (uroczystości w kościele) przez wydawanie zakazów. Czy ingerencja księży w przebieg uroczystości, która „należy” do nowożeńców, nie jest zbyt duża? Bardzo często nie znają się oni na tym, co atrakcyjne, popularne i modne.

5. Czy muzyczny repertuar jest dla księży rzeczywiście aż tak ważny, że wielu z nich stanowczo zabrania wykonywania na mszach ślubnych utworów wywołujących pozytywne emocje - refleksyjnych, podniosłych, rozbudzających fantazję i realizujących marzenia?

Odpowiedzi na zadane pytania trzeba zacząć od wytłumaczenia, choćby krótkiego, czym jest msza. Każda z takich celebracji (także ta, podczas której następuje składanie przyrzeczeń małżeńskich) jest uobecnieniem paschalnego misterium Chrystusa. Jest gromadzeniem się wierzących w Niego, wśród których staje się On obecny. Jest dziękczynieniem, jakie chrześcijanie składają Bogu Ojcu, przez Syna Bożego, w Duchu Świętym. W podanym objaśnieniu widać wyraźnie, że najważniejszy w tych celebracjach zawsze pozostaje Jezus Chrystus. Takimi, najważniejszymi, nie stają się nawet ci, którzy podczas mszy zawierają związek małżeński. Powyższa 
prawda o jednorodzonym Synu Bożym pozwala zrozumieć podaną na II Soborze Watykańskim naukę o muzyce liturgicznej: ona jest integralną i nieodzowną częścią świętych celebracji, służy oddawaniu chwały Bogu i uświęceniu wiernych, zawsze ma być ściśle związana z dokonującymi się świętymi czynnościami, aby w ten sposób zyskiwać świętość. ${ }^{29}$ Takie są kryteria dopuszczania utworów do liturgii. Jedynie repertuar spełniający te warunki będzie zgodny z jej duchem i powagą obrzędów. To dlatego Kościół zabrania wykonywania w ramach sprawowanych celebracji repertuaru, w którym tekst nie zawiera treści religijnych, a muzyka ma charakter świecki. ${ }^{30}$

Podane rozwiązanie problemu dopuszczenia do liturgii muzyki, jakim jest jej związek z celebrowanymi obrzędami, prowadzi do zauważenia dokonującej się w niej ingerencji Boga: decydujące dla liturgicznych utworów jest zobaczenie w nich Jego dotyku. Dzieje się tak wtedy, kiedy utwory wyrażają treści czytań biblijnych, przeżywanej danego dnia uroczystości czy trwającego okresu liturgicznego. W objawionym słowie, w celebrowanej tajemnicy wiary czy w rozważaniu zbawczych dzieł w jednym z okresów roku kościelnego wierni spotykają Boga i wychwalają Go pieśnią. W swoim sercu dostrzec mogą wówczas działanie Ducha Świętego i w wykonywanym repertuarze rozpoznają Jego mowę: przez takie działanie Trzeciej Osoby Boskiej dokonuje się zjednoczenie człowieka z Ojcem niebieskim. Istotną kwestią w prezentowanym zagadnieniu jest zatem zrozumienie, że to nie muzyka ma być przedmiotem zachwytu, ale to, do czego ona prowadzi - do coraz większej zażyłości z Bogiem. Fenomen właściwego repertuaru liturgicznego polega na traktowaniu go jako objawianie się Wszechmogącego. Muzyka - jak tłumaczy Hildegarda z Bingen, niemiecka mistyczka i kompozytorka - stanowi

29 Por. KL 112; I. Pawlak, Śpiewy i muzyka w sakramencie matżeństwa, Msza Święta 2/1970, s. 42.

30 Por. Instrukcja Episkopatu Polski o muzyce liturgicznej po Soborze Watykańskim II (8 II 1979), nr 20. 
drogę dotarcia do człowieka, ,zmiękcza twarde serca, i wprowadza w nie wilgoć skruchy oraz przyzywa Ducha Świętego". 31

Objaśniając kryteria przyjęcia utworu do liturgii, warto zaakcentować fakt, że praktyką niewłaściwą, i wyrządzającą duchową krzywdę, jest kierowanie się w tym rozstrzygnięciu upodobaniem jednostki. Zawsze należy mieć na względzie dobro duchowe wszystkich wiernych. Opiniowanie repertuaru, zwłaszcza nowych utworów, należy do powołanych w poszczególnych diecezjach komisji. Zadaniem każdej z nich jest czuwanie nad tym, aby muzyka liturgiczna odznaczała się świętością, pięknością formy i powszechnością. W ten sposób spełniać ona będzie stawiane jej dwa cele: oddawanie chwały Bogu i uświęcanie wierzących w Niego. ${ }^{32}$ Pamiętanie o realizacji tych celów pomaga $\mathrm{w}$ znajdywaniu właściwych odpowiedzi na pytania, które stawiają zainteresowani uroczystością zawarcia sakramentalnego związku małżeńskiego. Przykładem potwierdzającym taką drogę poszukiwania właściwych rozwiązań może być poruszona w niniejszym opracowaniu kwestia możliwości gry na skrzypcach. Używanie ich podczas liturgii nie jest zakazane, ale nie jest to instrument liturgiczny. ${ }^{33}$ Wykorzystanie go wymaga roztropności; często bowiem gra na nim wprowadza świeckość rytmu i melodii, praktykowana jest w celu wytworzenia zewnętrznego i spektakularnego uroku. W takim przypadku nie można mówić o realizacji stawianych muzyce liturgicznej celów.

Z prezentowanego nauczania wyraźnie wynika brak jakiejkolwiek możliwości wykonywania utworów niezgodnych z ustalonymi normami. One są bowiem niezależne od zmieniającej się mody czy osobistych upodobań kogokolwiek ze zgromadzonych na mszy świętej (np. nowożeńców). O jedynie słusznym rozwiązaniu omawianego

31 Cyt. za: B. Matusiak, Hildegarda z Bingen. Teologia muzyki, Kraków 2003, S. 125.

32 Por. KL 112.

33 Do instrumentów muzycznych, których użycie w świętych celebracjach - zgodnie z instrukcją KEP z 1979 r. - jest zakazane, należą: gitara elektryczna, perkusja, fortepian, syntezator. 
problemu przypomniał Franciszek uczestnikom kongresu Muzyka a Kościót: Kult a kultura w 50 lat od „Musicam Sacram”; nauczając o śpiewie, który dodaje celebrowanym czynnościom dostojeństwa, papież połączył go z możliwością bardziej intensywnego uczestnictwa w eucharystycznej „Tajemnicy Boga”. Kiedy wybiera się przeciętność i powierzchowność - zauważa - wtedy liturgia traci piękno i sobie właściwą głębię. ${ }^{34}$

Odznaczająca się pięknem celebracja stanowi dla wiernych sposobność doświadczania bliskości Boga i coraz dokładniejszego poznawania Go. Liturgia, której oprawa muzyczna dodaje majestatu, porywa umysły uczestniczących w niej do spraw niebiańskich. ${ }^{35}$ Wówczas bowiem - jak tłumaczył Benedykt XVI - ma miejsce „otwarcie się Nieba ku ziemi", ${ }^{36}$ wtedy można dostrzec - jak widzieli to trzej apostołowie (por. Mk 9,2) - wspaniałość Jezusa. Piękno muzyki zatem stwarza człowiekowi większą możliwość wyrażenia siebie obecnego w ludzkim sercu pragnienia zarówno oddawania należnej Bogu chwały, jak i coraz doskonalszego zjednoczenia z Nim (uświęcenia). Piękno pobudza człowieka do działania, pozwala na myślenie o woli Boga i dodaje sił do jej pełnienia. Uczestniczący w świętych obrzędach powinni więc zostać pouczeni o tym, że „wszędzie tam, skąd wyrzucono piękno i gdzie ceni się tylko rzeczy użyteczne, coraz wyraźniej widać przerażające zubożenie. (...) Kościół ograniczający

34 Por. Przemówienie papieża Franciszka o muzyce liturgicznej (4 III 2017), https://www.liturgia.pl/Przemowienie-papieza-Franciszka-o-muzyce-liturgicznej/ (dostęp: 5 VII 2019). Papieskie wskazania dotyczące wyboru repertuaru muzycznego na uroczystość zawarcia sakramentalnego związku małżeńskiego podawały wszystkie katolickie tygodniki w Polsce.

35 Por. KL 120; B. Nadolski, Liturgiczna muzyka, w: tenże (red.), Leksykon liturgii, Poznań 2006, s. 811: „Śpiew pojawia się w momencie, gdy człowiek w odpowiedzi na Boże działanie nie potrafi wyrazić w pełni dynamiki swojego doświadczenia religijnego".

36 Benedykt XVI, Posynodalna adhortacja apostolska „, Sacramentum Caritatis”, o Eucharystii, źródle i szczycie życia i misji Kościoła (22 II 2007), nr 35. 
się do wykonywania muzyki «modnej», «popularnej» popada w nieudolność i staje się nieprzydatny". ${ }^{37}$

Warto dodać, że w zawierających wytyczne dotyczące kościelnej muzyki dokumentach - wydawanych po II Soborze Watykańskim wyszczególniany jest sakrament małżeństwa; jako przykłady można przywołać choćby następujące teksty: „Należy jednak pilnie czuwać nad tym, by dla rzekomego podniesienia uroczystości nie wprowadzać do obrzędów czegoś całkiem świeckiego lub niezgodnego z powagą kultu Bożego; dotyczy to szczególnie zawierania małżeństwa"; 38 „Podobne zasady, jak w przypadku doboru pieśni do liturgii Mszy świętej, obowiązują również podczas sprawowania innych sakramentów, m. in. sakramentu małżeństwa. Pieśni wykonywane podczas celebracji sakramentu małżeństwa mają tworzyć z nią harmonijną całość zarówno pod względem treści, jak i formy". ${ }^{39}$

Wskazanie o tworzeniu harmonijnej całości muzyki z liturgią sakramentu znajduje swoje uzasadnienie w fakcie, że w sprawowanych obrzędach Bóg przemawia do swojego ludu. On kieruje swoje słowo na różne sposoby, wszelkimi środkami, jakimi dysponuje Kościół. Muzyka, z właściwą sobie funkcją służebną, pomaga wiernym postępować drogą coraz lepszego rozumienia zbawczego przekazu. Oprócz ułatwiania rozumienia tego orędzia, ona pomaga - przez umożliwienie wiernym zaangażowania się uczuciowo - w przyjęciu znajdującego się w nim bogactwa głębi wiary. Poprawnie dobrane i właściwie wykonane podczas celebracji utwory spełniają funkcję

37 J. Klecel (red.), Raport o stanie wiary. Z ks. kardynałem Josephem Ratzingerem rozmawia Vittorio Messori, tłum. Z. Oryszyn, Kraków-Warszawa-Struga 1986, s. 110-111; por. J. Ratzinger, Nowa Pieśń dla Pana, Kraków 1999, s. 170-173.

38 Święta Kongregacja Obrzędów, Instrukcja „Musicam Sacram” o muzyce $w$ świętej liturgii (5 III 1967), nr 43.

39 A. Jeż, List pasterski Biskupa Tarnowskiego na temat roli muzyki w liturgii z okazji jubileuszu 50-lecia działalności Diecezjalnego Studium Organistowskiego $w$ Tarnowie (10 XI 2015). 
kerygmatyczną - pokazują zbawcze działanie Boga, umacniają wiarę, stają się językiem modlitwy. ${ }^{40}$

W celu pełniejszego poznania znaczenia teologicznych wartości muzycznego repertuaru dla sakramentu małżeństwa warto odwołać się do treści biblijnej Księgi Pieśni nad pieśniami. Jej fragment (2, 8-10.14.16a; 8, 6-7a) znajduje się w propozycjach czytań omawianych obrzędów liturgicznych. Przesłaniem tego starotestamentalnego tekstu - jak komentuje Orygenes - pozostaje prawda o Bogu, który jest Kimś, kto nadaje sens miłości; „na uznanie zasługuje jedynie taka miłość, która ma związek z Bogiem i z cnotami duchowymi”. ${ }^{41}$ Wszechmogący sprawia, że jest ona idealna i duchowa, naznaczona duchowymi i moralnymi wartościami, odznacza się wolnością i łaskawością. ${ }^{42}$

Powyższa prawda uzasadnia konieczność przestrzegania obowiązujących wskazań kościelnych, które dotyczą analizowanej muzyki. One jednak, dzięki treściom Pieśni nad pieśniami przestają być jedynie normami prawa liturgicznego; stają się również sposobem zbawczego dialogu między stworzeniami a Stwórcą. Przestrzeganie ich pozwala usłyszeć Boga, który zarówno wypowiada się na temat ludzkiej miłości, jak i ją wydoskonala. Przez właściwy repertuar muzyczny - i tylko taki - dokonuje się bowiem poznanie Wszechmogącego, Jego zbawczego działania. Dzięki poznaniu Go, składający sakramentalną przysięgę małżeńską nowożeńcy z przekonaniem i z potrzeby serca proszą: „Tak mi dopomóż, Panie Boże Wszechmogący”.

40 Por. R. Tyrała, Duszpasterski wymiar muzyki liturgicznej w świetle adhortacji „Sacramentum caritatis”, Łódzkie Studia Teologiczne 17/2008, s. 386.

${ }^{41}$ A. Papierzowa (red.), Orygenes. Komentarz do „Pieśni nad pieśniami”. Homilie o „Pieśni nad pieśniami”, tłum. S. Kalinowski, Kraków 1994, s. 19.

42 Por. J. Drozd, Wstęp do Pieśni nad pieśniami, w: M. Peter (red.), Stary Testament, t. 2: Księga Tobita. Księga Judyty. Księga Estery. Księga Rut. Księga Psalmów. Księga Przystów. Księga Joba. Pieśń nad pieśniami. Księga Koheleta. Mądrość Syracha. Księga Mądrości, Poznań 1999, s. 475. 
Pieśń nad pieśniami wychwala miłość oblubieńczą, której sprawcą jest Stwórca. On objawia w tej starotestamentalnej księdze swój zamysł względem człowieka:

- o powołaniu go do małżeństwa monogamicznego;

- o obdarowywaniu go miłością, która (mimo tego, że czasami można ją zagubić) poszukuje coraz doskonalszego daru z siebie;

- o wyborze miłości, który naznaczony jest całkowitą wolnością i łaskawością;

- o obecnym w sercu człowieka zaślubionego pragnieniu nierozerwalności małżeństwa;

- o potrzebie pomagania zaślubionym przez tych, którzy żyją obok nich;

- o celu wspólnego życia przez małżonków, jakim jest pokój. ${ }^{43}$

Wiodącym tematem przywołanej biblijnej księgi jest miłość Boży dar, który najdokładniej opisuje ludzkie serce. Dlatego też - co akcentują w swoich badaniach biblijni egzegeci - miłość ludzka to przeżywanie codzienności, które buduje się na fundamencie „otwarcia na transcendentne doświadczenie JHWH”. ${ }^{44}$ Miłość jest „„płomieniemPana” (por. Pnp 8,6). Tak więc muzyka liturgiczna, przez którą Bóg przybliża człowieka do siebie, stanowi sposobność poznania i przyjęcia Jego miłości.

Przedstawione powyżej treści pozwalają na udzielenie jednoznacznej odpowiedzi na często powtarzające się pytanie - dotyczące muzycznego repertuaru ślubnego - o nadmierne wymagania. Często obwiniani są za nie ci, którzy przewodniczą liturgii i są za nią odpowiedzialni, czyli kapłani. Trzeba przyznać, że dla kogoś, kto nie zna bądź nie rozumie nauczania Kościoła, normy prawa

${ }_{43}$ Por. A. Stus, J. Warzecha, J. Frankowski (red.), Wprowadzenie w myśl $i$ wezwanie ksiag biblijnych, t. 7: Pieśni Izraela. Pieśn nad pieśniami, Psalmy, Lamentacje, Warszawa 1988, s. 167-170.

${ }^{44}$ M. T. Elliot, Pieśń nad Pieśniami, w: W. Farmer (red.), Międzynarodowy komentarz do Pisma Świętego. Komentarz katolicki i ekumeniczny na XXI wiek, Warszawa 2000, s. 793. 
liturgicznego mogą okazać się zbyt trudne. Wówczas konsekwentnie będzie dążył do omijania tych przepisów lub obwiniał tych, którzy są odpowiedzialni za ich przestrzeganie. Jedynie poznanie norm - także tej, w której zaznaczono, że kapłan jest „sługą świętej liturgii" i nie wolno mu w niej niczego zmieniać ${ }^{45}$ - może sprawić właściwe ich przyjęcie i wypełnienie. One nie stanowią zbyt wygórowanych wymagań. „«Jeśli wnikliwiej to rozpatrzymy - tłumaczył Benedykt XVI powołując się na św. Augustyna - stwierdzimy, że to sprawa miłości». Lud Boży zebrany na celebracji śpiewa chwałę Bogu. Kościół, w swej dwutysiącletniej historii tworzył i nadal tworzy muzykę i śpiewy, które stanowią dziedzictwo wiary i miłości, i których nie należy zagubić". 46

Wskazanie kapłanów jako odpowiedzialnych za celebrowaną przez każdego z nich liturgię, jest przypomnieniem o nieustannej potrzebie właściwej formacji muzycznej duszpasterzy. Do ich zadań należy bowiem animowanie życia muzycznego we wspólnocie parafialnej, które polega m.in. na przygotowaniu pieśni, sprawdzeniu przygotowanego przez organistę czy scholę repertuaru liturgicznego, podawaniu obowiązujących w Kościele norm dotyczących śpiewu. ${ }^{47}$ Jeśli przekazywanie takiej nauki powinno być skierowane do wszystkich wiernych, szczególnie członków chóru i scholi, to - jak wynika z przywołanych wcześniej instrukcji o muzyce (wydanych przez Konferencję Episkopatu Polski, biskupów diecezjalnych w Tarnowie i Kielcach) - to obejmować ono powinno także nowożeńców. W ten sposób będą oni mogli przyczyniać się do właściwego sprawowania sakramentu małżeństwa. O takiej praktyce przypomniano we Wstępie (w punkcie 5) do księgi obrzędów zawierania związku małżeńskiego:

45 Por. Kongregacja Kultu Bożego i Dyscypliny Sakramentów, Ogólne wprowadzenie do mszału rzymskiego. Z trzeciego wydania mszału rzymskiego (Rzym 2002), nr 24.

46 Benedykt XVI, Posynodalna adhortacja apostolska ,, Sacramentum Caritatis", nr 42.

47 Por. K. Szymonik, Nauczanie muzyki, w: R. Tyrała (red.), Musicam Sacram Promovere. Dyskusja panelowa, Kraków 2004, s. 93; T. Lisiecki, Problemy formacji muzycznej duchownych w Polsce, Roczniki Teologiczne 63(2016) nr 8, s. 110. 
kandydatom do tego sakramentu należy omówić celebrację, aby mogli świadomie i owocnie w niej uczestniczyć. ${ }^{48}$

Przyjęcie odpowiedzialności za liturgię przez sprawujących ją kapłanów nie należy do zadań łatwych, jednak - jak tłumaczy Jean Galot, akademicki wykładowca teologii dogmatycznej - w realizowaniu go pomaga prawda o wypełnianiu przez nich misji Dobrego Pasterza. Mają oni troszczyć się o duchowe posilanie ludzkości; nieustannie pasterską misją pozostaje troska o to, by każdy człowiek posiadał życie i posiadał je w obfitości (por. J 10, 10). ${ }^{49}$ Jeśli w programach duszpasterskich Kościoła w Polsce znajdują się wezwania do podejmowania działań mających na celu ożywienie życia duchowego wiernych, to wciąż aktualnym zadaniem pastoralnym pozostaje formacja liturgiczna; przez muzykę, będącą integralną częścią świętych obrzędów, dokonuje się głoszenie tajemnicy wiary. Ona jest pastoralnym sposobem działania Kościoła.

Jeśli oboje nowożeńcy wiedzą o tym, że muzyka liturgiczna jest dziedzictwem wiary i miłości, to nigdy nie wybiorą innego repertuaru, jak tylko taki, który umożliwia im dostrzeżenie dokonującego się w nich obdarowania nadprzyrodzonym bogactwem. Hojny, w swej łaskawości, i miłosierny Bóg - w tak ważnym dla tych obojga momencie - pragnie umieścić w ich sercach orędzie zbawienia. Przyjęcie tego orędzia szczęścia - zarówno doczesnego, jak i wiecznego zależy od wiary i miłości, które ożywia i pomnaża także muzyka liturgiczna. ${ }^{50}$

Na temat związku muzyki liturgicznej z chrześcijańską postawą miłości wypowiadał się wielokrotnie ks. Ireneusz Pawlak. Wzajemne ich powiązanie tłumaczył następującymi argumentami:

48 Por. Obrzędy sakramentu matżeństwa dostosowane do zwyczajów diecezji polskich, Katowice 2008.

49 Por. J. Galot, Wybrane zagadnienia z teologii współczesnej, Kraków 1994, s. $100-101$.

50 Por. P. Maciaszek, Piękno liturgii droga Kościoła ewangelizującego i ewangelizowanego, Sosnowieckie Studia Teologiczne 12/2015, s. 244. 
1. W liturgii wzbogaconej właściwym repertuarem muzycznym dostrzec można „,prawo nadmiaru”, w którym dostrzega się miłość (która zawsze chce obdarowywać coraz hojniej). Jeśli Bóg jest dawcą łask w nadmiarze, to również wierzący w Niego powinni swoje dary ofiarowywać wielkodusznie.

2. Muzyka wyszczególnia ważny w życiu człowieka moment składania darów Bogu.

3. Wyrażanie miłości domaga się formy uroczystej.

4. Zaniechanie w liturgicznych celebracjach śpiewu jest przejawem skąpstwa w wychwalaniu Wszechmogącego.

5. Nauka śpiewu i wykonywanie go podczas sprawowanych obrzędów jest procesem formacji człowieka do oddawania Bogu tego, co najlepsze i najpiękniejsze.

6. Kierowanie się w świętych celebracjach minimalizmem (przejawiającym się w niedbałym śpiewie lub jego całkowitym odrzuceniu) prowadzi do zmniejszania się miłości i coraz większego niszczenia godności liturgii. ${ }^{51}$

$* * *$

Prezentacja zagadnienia doboru repertuaru muzycznego liturgii sakramentu małżeństwa została dokonana w świetle przekazu medialnego, dostrzegalnych obecnie trendów kulturowych i refleksji teologiczno-liturgicznej Kościoła. W przedstawieniu podjętego tematu wykorzystano treści zamieszczone w mediach cyfrowych. Wybrane źródło czyni tę część opracowania nowatorską; we wcześniejszych publikacjach nie sięgano do tego rodzaju form przekazu. Współcześnie żyjące młode pokolenie, którego przedstawiciele najliczniej zawierają sakramentalne związki małżeńskie, najczęściej korzysta z mediów społecznościowych. W nich właśnie nie tylko szuka potrzebnych informacji i wymienia opinie, lecz także zadaje ważne dla siebie pytania i poszukuje na nie odpowiedzi. Jeśli podjęty temat nie

${ }^{51}$ Por. I. Pawlak, Muzyka liturgiczna po Soborze Watykańskim II w świetle dokumentów Kościoła, Lublin 2000, s. 79. 
jest dla teologów i muzykologów nowy - i wydawać się może, że związane z nim wszelkie problemy zostały rozwiązane - to pierwsza część obecnego opracowania uzasadnia jego aktualność i klarownie określa dyskutowane w społeczeństwie kwestie.

W niniejszej prezentacji - co także stanowi nowy aspekt analizowanego problemu - wskazano też na przyczyny istniejącej sytuacji. Z wypowiedzi użytkowników mediów społecznościowych wynika, że mają one podłoże kulturowe, osobistych potrzeb emocjonalnych, błędnego rozumienia liturgii sakramentów świętych i ich znaczenia dla codziennego życia człowieka.

Po dostrzeżeniu problemu i wskazaniu źródeł jego istnienia podane zostały sposoby rozwiązania; droga właściwego doboru muzycznego repertuaru sakramentu małżeństwa przebiega przez obszar teologii. Wyraźnie wskazane w mediach i wymagające wyjaśnień aktualne kwestie związane z tymi świętymi celebracjami zostały wytłumaczone w świetle nauki Kościoła - Pisma Świętego, teologii prawa liturgicznego i sakramentalnych obrzędów. Sprawowana liturgia nigdy nie może być traktowana jako ,prywatna własność kogokolwiek, ani samego celebransa, ani wspólnoty, w której sprawuje się sakramenty". ${ }^{2}$ Przestrzeganie tych wskazań zarówno stanowi o autentyczności liturgii (która jest podarowana przez Chrystusa i polecana wspólnocie Kościoła), jak i decyduje o pięknie tych świętych obrzędów (na którym z pewnością zależy obojgu nowożeńcom). Zachowywane normy nie tylko gwarantują celebrowanym czynnościom świętość, lecz także bronią je przed wszystkim, co zagrażałoby przeżywaniu ich w sposób właściwy - świadomy i aktywny. ${ }^{53}$

Zamieszczane w internetowym przekazie treści muszą być zauważane przez teologów (także teologów kultury i mediów). Przekaz ten $-\mathrm{z}$ racji na aktualność i ważność - powinien być przedmiotem

52 Kongregacja ds. Kultu Bożego i Dyscypliny Sakramentów, Instrukcja „Redemptionis Sacramentum”, nr 12.

53 Por. K. Rzepka, Normy i wskazania liturgiczne dotyczace muzyki, dekoracji i fotografowania, https://przemyska.pl/2016/11/25/normy-i-wskazania-liturgiczne-dotyczace-muzyki-dekoracji-i-fotografowania/ (dostęp: 17 VII 2019). 
naukowej analizy. Podjęty temat z pewnością należy do tych, które wymagają teologicznej refleksji. Nie można ulec przekonaniu, że po II Soborze Watykańskim o muzyce liturgicznej powiedziano już tak wiele, że wierni nie mają żadnych związanych z nią pytań, sugestii i problemów. Nowe media - w których zdumiewa szybkość wymiany informacji i opinii o życiu społeczeństwa - i zmieniająca się kulturowa moda nie mogą pozostawać bez głosu teologów. Głos ten powinien stanowić odpowiedź na - dotyczące doczesnego i wiecznego życia człowieka - podawane opinie i spostrzeżenia. Do takich stwierdzeń należy następująca wypowiedź papieża Franciszka o muzyce liturgicznej: „Zachodzące przemiany społeczne i kulturowe oraz postępująca sekularyzacja życia dotykają także liturgii. Przyczyna tego zjawiska tkwi przede wszystkim w fałszywym poczuciu wolności oraz nieznajomości nauki Kościoła". ${ }^{54}$

Powyższa prezentacja z pewnością wykazała niedostateczne doinformowanie w podjętych kwestiach tych, którzy przygotowują się do uroczystości złożenia sakramentalnej przysięgi małżeńskiej podczas mszy świętej. Aktualne i pilne wydaje się zatem pytanie, czy zagadnienie właściwego doboru repertuaru muzycznego podejmowane jest podczas kursów przedmałżeńskich bądź wyjaśniane w przekazie informacji, które duszpasterze kierują do swoich parafian (treści dotyczące celebracji sakramentów świętych zamieszczane są na przykład w parafialnych gazetkach czy na stronach internetowych). Potrzebę takiej praktyki można (i trzeba) określić jako pilną; przedstawiana i żywo komentowana w mediach rzeczona kwestia wydaje się rzeczywiście skomplikowana dla kandydatów do małżeństwa.

ks. Pawet MACIASZEK

54 Przemówienie papieża Franciszka o muzyce liturgicznej. 
Słowa kluczowe: sakrament małżeństwa; muzyka liturgiczna; pieśni kościelne; kultura; media

Keywords: sacrament of marriage; liturgical music; church songs; culture; media

\title{
Musical Repertoire for the Celebration of the Sacrament of Marriage: Media, Cultural and Liturgical Aspects
}

\author{
Summary
}

The choice of musical repertoire for the celebration of the sacrament of marriage has become the subject of more frequent and widespread discussions. Media publications on the subject which provide suggestions for the choice published in the media and promoted cultural solutions for music attest to the existence of a problem and the urgent need to arrive at some form of resolution. In this article, the issue of music and songs at church weddings is presented in three parts: the first clarifies the existing problem; the second shows the cultural factors which have led to the existence of the problem; the third part demonstrates the urgent need to formulate a rightful solution regarding the choice of music within the context of Christian liturgy. Suggestions for this choice put forward in the mass media, together with current cultural trends, do not always advocate appropriate choices.

The guidelines given to the bridal couple in order to assist them in their choice of music should always be in keeping with liturgical law. The rules and regulations which govern liturgical law lead to a deeper understanding among the faithful of the true meaning of sacramental rituals and their Christian significance. Consequently, they can never be subject to personal taste alone. Observance of these regulations ensures the Christian authenticity of the liturgy as ordained by Christ and the Christian community, and it enhances the aesthetic aspect; indeed, every bridal couple wishes their nuptial Mass to be beautiful. Consequently, they should be made acquainted with the Church's teaching on liturgical musical settings. Adherence to prescribed norms not only guarantees the essential holiness of the liturgical celebration, but also ensures that their sanctity is not undermined, and allows for inclusive participation in the liturgy. 


\section{Bibliografia}

Drozd J., Wstęp do Pieśni nad pieśniami, w: M. Peter (red.), Stary Testament, t. 2: Księga Tobita. Księga Judyty. Księga Estery. Księga Rut. Księga Psalmów. Księga Przystów. Księga Joba. Pieśń nad pieśniami. Księga Koheleta. Madrość Syracha. Księga Mądrości, Poznań 1999, s. 472-477.

Galot J., Wybrane zagadnienia z teologii współczesnej, Kraków 1994.

Instrukcja Episkopatu Polski o muzyce liturgicznej po Soborze Watykańskim II (8 II 1979).

Instrukcja Konferencji Episkopatu Polski o muzyce kościelnej (14 X 2017).

Kongregacja ds. Kultu Bożego i Dyscypliny Sakramentów, Ogólne wprowadzenie do mszału rzymskiego. Z trzeciego wydania mszału rzymskiego, Rzym 2002.

Lisiecki T., Problemy formacji muzycznej duchownych w Polsce, Roczniki Teologiczne 63(2016) nr 8, s. 107-120.

Maciaszek P., Naznaczyć życie muzyka liturgiczną. Rozmowy o roli muzyki w różnych wyznaniach chrześcijańskich, Częstochowa 2012.

Maciaszek P., Piękno liturgii droga Kościoła ewangelizującego i ewangelizowanego, Sosnowieckie Studia Teologiczne 12/2015, s. 231-248.

Matusiak B., Hildegarda z Bingen. Teologia muzyki, Kraków 2003.

Nadolski B., Liturgiczna muzyka, w: tenże (red.), Leksykon liturgii, Poznań 2006, s. 811-815.

Obrzędy sakramentu matżeństwa dostosowane do zwyczajów diecezji polskich, Katowice 2008.

Papierzowa A. (red.), Orygenes. Komentarz do „Pieśni nad pieśniami”. Homilie o „Pieśni nad pieśniami”, tłum. S. Kalinowski, Kraków 1994.

Pawlak I., Muzyczna kultura Kościoła - zagrożona, Liturgia Sacra 9(2003) nr 1, s. 87-92.

Pawlak I., Muzyka liturgiczna po Soborze Watykańskim II w świetle dokumentów Kościoła, Lublin 2000.

Pawlak I., Śpiewy i muzyka w sakramencie matzeństwa, Msza Święta 2/1970, s. $40-42$.

Ratzinger J., Nowa Pieśń dla Pana, Kraków 1999.

Sobór Watykański II, Konstytucja „Sacrosanctum Concilium” o liturgii świętej (4 XII 1963).

Strus A., Warzecha J., Frankowski J. (red.), Wprowadzenie w myśl i wezwanie ksiag biblijnych, t. 7: Pieśni Izraela. Pieśń nad pieśniami, Psalmy, Lamentacje, Warszawa 1988.

Szymonik K., Nauczanie muzyki, w: R. Tyrała (red.), Musicam Sacram Promovere. Dyskusja panelowa, Kraków 2004, s. 93-94. 
Święta Kongregacja Obrzędów, Instrukcja „Musicam Sacram” o muzyce $w$ świętej liturgii (5 III 1967).

Tyrała R., Duszpasterski wymiar muzyki liturgicznej wświetle adhortacji „Sacramentum caritatis”, Łódzkie Studia Teologiczne 17/2008, s. 385-403.

$* * *$

AK, Powstanie lista „piosenek zakazanych” na ślubie. Tych utworów już nie ustyszysz! https://gazetakrakowska.pl/powstanie-lista-piosenek -zakazanych-na-slubie-tych-utworow-juz-nie-uslyszysz/ar/13277201.

Barwiński D., Jakie utwory moga być grane na ślubie w Kościele, https://www.abcslubu.pl/slub-i-wesele/muzyka-na-wesele/4720/jakie -utwory-moga-byc-grane-na-slubie-w-kosciele.

Batycki W., Muzyka w czasie liturgii sakramentu małżeństwa (17 listopada 2016), https://diecezja.zamojskolubaczowska.pl/wiadomosci/1137 -muzyka-w-czasie-liturgii-sakramentu-malzenstwa.

Benedykt XVI, Posynodalna adhortacja apostolska ,Sacramentum Caritatis" o Eucharystii, źródle i szczycie życia i misji Kościoła (22 II 2007).

Bobek Ł., Kościelisko. Ślub w stylu Gwiezdnych Wojen, https://gazetakrakowska.pl/koscielisko-slub-w-stylu-gwiezdnych-wojen-galeria/ar/9222380.

Doniec G., Dlaczego na ślubie nie będzie Alleluja ze Shreka? https://www. liturgia.pl/Dlaczego-na-slubie-nie-bedzie-Alleluja-ze-Shreka/.

Episkopat. pl, om, Episkopat wydat instrukcję o muzyce kościelnej. Koniec pobłażliwości dla ,Hallelujah” ze Shreka, https://www.pch24.pl/episkopat-wydal-instrukcje-o-muzyce-koscielnej-koniec-poblazliwosci-dla-hallelujah-ze-shreka,55401,i.html.

Ewelina, Komentarz. Coraz mniej ślubów (23 VI 2018), https://gazetakrakowska.pl/powstanie-lista-piosenek-zakazanych-na-slubie -tych-utworow -juz-nie-uslyszysz/ar/13277201.

IB, Tego nie ustyszysz na ślubie. Powstanie lista ,piosenek zakazanych”? https://www.fakt.pl/wydarzenia/polska/krakow/tarnow-powstanie -lista-piosenek-zakazanych-na-slubie/lxrly5j.

Jaćkiewicz Ł., Tych piosenek nie ustyszysz na ślubie. Na liście Abba, The Beatles czy Leonard Cohen, https://allaboutmusic.pl/biskup/.

Jak dobrać muzykę na ślub w kościele? https://www.slubnaglowie.pl/inspiracje/ artykul/jak-dobrac-muzyke-na-slub-w-kosciele.

Jeż A., List pasterski Biskupa Tarnowskiego na temat roli muzyki w liturgii z okazji jubileuszu 50-lecia działalności Diecezjalnego Studium Organistowskiego w Tarnowie (10 XI 2015), http://czermna.diecezja.tarnow. $\mathrm{pl} /$ ?list-pasterski-biskupa-tarnowskiego-na-temat-roli-muzyki-w-liturgii. 
$\mathrm{JZ//rzw} \mathrm{/} \mathrm{tvn24,} \mathrm{,Nie} \mathrm{każdy} \mathrm{instrument} \mathrm{odpowiada} \mathrm{godności} \mathrm{światyni”.} \mathrm{Co}$ i jak może grać w kościele, https://www.tvn24.pl/wiadomosci-z-kraju,3/ biskupi-przyjeli-instrukcje-o-muzyce-koscielnej,781531.html.

Klecel J. (red.), Raport o stanie wiary. Z ks. kardynatem Josephem Ratzingerem rozmawia Vittorio Messori, tłum. Z. Oryszyn, Kraków-Warszawa-Struga 1986.

Kongregacja ds. Kultu Bożego i Dyscypliny Sakramentów, Instrukcja „Redemptionis Sacramentum” o tym, co należy zachowywać, a czego unikać w związku z Najświętsza Eucharystia (25 III 2004).

Krupor, Komentarz (12 VIII 2017), https://www.abcslubu.pl/slub-i-wesele/muzyka-na-wesele/4720/jakie-utwory-moga-byc-grane-na -slubie-w-kosciele\#comment31383.

Lewandowski M., Decyzja dot. „zakazanych piosenek” wywołała goraca dyskusję. Oto najciekawsze komentarze, https://www.deon.pl/religia/kosciol-i-swiat/z-zycia-kosciola/art,34667,decyzja-dot-zakazanych-piosenek-wywolala-goraca-dyskusje-oto-najciekawsze-komentarze.html.

ME, Komentarz (1 V 2018), https://www.abcslubu.pl/slub-i-wesele/muzyka-na-wesele/4720/jakie-utwory-moga-byc-grane-na-slubie-w-kosciele \#comment31656.

Muzyk, Skrzypek, Chrześcijanin, Wierzący, Praktykujący, Komentarz (15 X 2017), http://piosenkireligijne.pl/piesni-na-slub/.

Piosenki na ślub kościelny i cywilny - najmodniejsze piosenki ślubne, https:// www.eska.pl/news/piosenki-na-slub-koscielny-i-cywilny-najmodniejsze-piosenki-slubne-aa-PEEh-p1Zq-FKxj.html.

Piotrowska L., Czarna lista piosenek na ślub kościelny. Biskup zakazat kolejnych hitów, https://www.papilot.pl/zwiazki/slub-i-wesele/43009/ piosenki-zakazane-w-kosciolach.

Piotrowski J., Instrukcja dotyczaca muzyki i śpiewu liturgicznego dla diecezji kieleckiej (22 XI 2018), http://www.diecezja.kielce.pl/sites/default/ files/instrukcja_dotyczaca_muzyki_i_spiewu_liturgicznego_dla_diecezji_kielckiej.pdf.

Przemówienie papieża Franciszka o muzyce liturgicznej (4 III 2017), https:// www.liturgia.pl/Przemowienie-papieza-Franciszka-o-muzyce-liturgicznej/.

Rymsza M., Matzeństwo nie jest sprawa prywatna, http://wiez.com. $\mathrm{pl} / 2017 / 02 / 03 /$ malzenstwo-nie-jest-sprawa-prywatna/.

Rzepka K., Normy $i$ wskazania liturgiczne dotyczace muzyki, dekoracji i fotografowania, https:/przemyska.pl/2016/11/25/normy-i-wskazania-liturgiczne-dotyczace-muzyki-dekoracji-i-fotografowania/. 
Skrzypaczka. Wokal. Skrzypce na ślub i inne uroczystości, https://www. weselezklasa.pl/ogloszenia-weselne/skrzypaczka-na-slub-i-inne -uroczystosci-koscielne,32248/.

Wadowski M., Piosenek Abby i Beatlesów na ślubie nie ustyszymy. Biskup wydat instrukcje, http://kielce.wyborcza.pl/kielce/7,47262,24218674,piosenek-abby-i-beatlesow-na-slubie-nie-uslyszymy-biskup-wydal.html. 